\title{
Correction to: Mid-upper-arm circumference based case-detection, admission, and discharging of under five children in a large-scale community-based management of acute malnutrition program in Nigeria
}

\author{
Stanley Chitekwe ${ }^{1}$, Sibhatu Biadgilign ${ }^{{ }^{*}}$, Assaye Tolla ${ }^{1}$ and Mark Myatt ${ }^{2}$
}

\section{Correction}

The author requests to correct errors in the original article [1]. Area where it needs amendment are as follows.

1. In conclusion section of Abstract:

"This study confirms that MUAC can be used for both admitting and discharging criteria in CMAM programs with MUAC $<115 \mathrm{~mm}$ for admission and MUAC > 125 $\mathrm{mm}$ or at discharge (a higher discharge threshold could be used)."

Replaces

"This study confirms that MUAC can be used for both admitting and discharging criteria in CMAM programs with MUAC $<115 \mathrm{~mm}$ for admission and MUAC $>=115 \mathrm{~mm}$ or at discharge (a higher discharge threshold could be used)."

2. In Table 1:

1) All "MUAC $>115 \mathrm{~mm}$ " should be changed into "MUAC > $125 \mathrm{~mm}$ " under each of the discharge criteria column.

2) Superscript "a" above the "well" should be removed.

3) The legend under the table should be removed.

\section{Author details}

'United Nations Children's Fund (UNICEF), Nigeria country office, UN House, Plot 617/618 Central Area District Diplomatic Zone, Garki, Abuja B 2851, Nigeria. ${ }^{2}$ Consultant Epidemiologist, Brixton Health, Llawryglyn, Wales, UK.

\footnotetext{
* Correspondence: sibhatu2010@gmail.com

'United Nations Children's Fund (UNICEF), Nigeria country office, UN House, Plot 617/618 Central Area District Diplomatic Zone, Garki, Abuja B 2851, Nigeria

Full list of author information is available at the end of the article
}

Published online: 28 June 2018

\section{Reference}

1. Chitekwe et al. Mid-upper-arm circumference based case-detection, admission, and discharging of under five children in a large-scale community-based management of acute malnutrition program in Nigeria. Archives of Public Health (2018) 76:19. https://doi.org/10.1186/s13690-0180266-4.
Ready to submit your research? Choose BMC and benefit from:

- fast, convenient online submission

- thorough peer review by experienced researchers in your field

- rapid publication on acceptance

- support for research data, including large and complex data types

- gold Open Access which fosters wider collaboration and increased citations

- maximum visibility for your research: over 100M website views per year

At $B M C$, research is always in progress.

Learn more biomedcentral.com/submissions 